Journal of Education and Vocational Research

Vol. 6, No. 2, pp. 42-47, June 2015 (ISSN 2221-2590)

\title{
Work Responsibilities Stress among Academicians in Private Universities in Malaysia
}

\author{
Sabarudin Zakaria, Nurhaya Omar, Arnifa Asmawi \\ Multimedia University, Cyberjaya, Selangor, Malaysia \\ sabarudin.zakaria@mmu.edu.my
}

\begin{abstract}
Increasing numbers of private universities in Malaysia has caused a great competition and expectation that forces the education providers to offer synergy and value-added services to their students. High expectation form students, financial constraint, countless job responsibilities and 'education as business' orientation adopted by private universities, are among stressors to its academicians. Thus cause dangerous health complication; hypertension, heart attack, migraine, depression, eating disorder, besides some consider migrating and leaving their job. This study aims to explore the causes and main contributor of stress among these academicians with regards to job responsibilities of teaching, researching and administrative task. The gained result at the end of this study is not entirely purpose to change the whole academician job scope in the industry, but as a guide be it university or the government, in designing or developing new policy for their respective institutions.
\end{abstract}

Keywords: Stress, private university, academic staff, teaching, research

\section{Introduction}

Stiff competition among private universities in Malaysia has force the education providers to offer synergy and value-added services to their students (Halim et al., 2014). Besides focusing on getting student enrolment to ensure revenue generation, private universities are also required to build up prestige by offering advance and relevant courses to cater with industrial demand (Bunoti, 2011). With more expectation towards these private universities, academician, who act as education medium are expected to play more dynamic role in the provision of education, training and research facilities to meet the arising demand for professional and skilled manpower, also the demand to uphold university status through quality teaching and research (Pey, 2009). Since the dramatic changes in socio-economic life, academic profession has become highly demanding (Nazari \& Emami, 2012). Academician's job responsibility in most university's has surpass a paradigm shift, where they are no longer required to do only teaching but to produce research, seeking research grant, publish papers for conferences and journals, supervising students, consulting and guiding students and not to mention the growing demand for administrative work such invigilating exams, committees for student affair, research, course management, reporting, syllabus enhancement as well as attend numbers of meeting that take up most of their times thus caused work-life imbalance (Levin, 1991; Jaschik, 2013). While in the teaching environment, researchers have created concern on the role stress among teachers where many role demands are at present. This the role demand may become stressful to teacher when expectation of organizational member towards teacher is unclear (role ambiguity), with excessive work load (role overload), or meeting led to expectations more difficult because of too many role conflict.

Even in private universities following the culture in public universities, academicians are emphasized not to only to teach but also to produce research paper in accordance to its university management structure and nature (Pey, 2009). Although private universities are less bound by governmental and bureaucratic regulations, financial constraint has often become the greatest challenge to these institutions and its academicians, where they have to creatively seeking fund through enhancement of program quality and delivery. At the same with more demand from the faculty to produce a research with commercial value. Beyond teaching and research duties, academicians are also responsible to participate in numerous committee in university such research, student affairs, computer lab, course management and many more, as this will affect the merit given during yearly assessment (Pey, 2009). This creates competition with public higher learning which was treated as major challenge for academicians in private universities as stated by Arokiasamy et al. (2009) that; 
"the prestige and appropriate standardize policy system in public university has somehow build a challenge towards academician in newly developed private universities as they encounter the pressure to be productive by maintaining high quality standard. Besides having to work independently in terms of funding with limited resources, these academicians in private universities are also expected to produce outstanding research publication".

\section{Literature Review}

Stress is uncommonly difficult to define, even though the word itself is universally understood (Simha et al., 2011). Stress and its adverse effects have been studied since the era of Aristotle, Hippocrates and other ancient scholars (Fink, 2010). Greek physicians of the school of Hippocrates (460 - 377 BCE) recognized a disorder characterized by symptoms commonly seen in stress illness today: palpitations, migrating pain, difficulty breathing, a lump in the throat and others (Porter, 1997). The stress concept was then being formally explained by Claude Bernard (1813 - 1878) a French physiology, in a concept called 'Milieu Interieur' or 'The Internal Environment of Body' in 1859 which suggested that constancy or a steady state (situation) in internal body is essential to survival and external changes in environment or external forces could lead to the changes in the internal body system (Fink, 2010). According to Smith (1997) and Kalleberg (2001) role stress can be contributed by switching or changing of organizational focus, flexibility and employee empowerment which led to changing of job specifications and uncertainty, moreover, losing job stability is a subsequently increase potential for job role stress (Cooper \& Dewe, 2004). Roles stress is viewed as detrimental to employee as well as organizational outcome such job tension, job dissatisfaction, employee turnover and employee burnout also diminishing of organizational commitment and burnout (Fisher \& Gitelson, 1983; Jackson \& Schuler, 1985; Van Sell et al., 1981; Lee, 1997; Johnson et al., 1990).

Generally, stress according to Oxford dictionary is a state of mental or emotional strain or tension resulting from adverse or demanding circumstances (Oxford University Press, 2014). According to a famous psychology scholar, Professor Richard S. Lazarus (2000) stress occurs when an individual perceives demand of an external situation beyond his or her perceived ability to cope with them. Stress level among academician has started to indicate a worrisome trending with the evidence of these academician experience a dangerous health complication such hypertension, heart attack, migraine, depression, eating disorder (Juliana \& NurAqilah, 2012) besides some consider to migrate and leaving job (Hurtado et al., 2012) and even worst; commit suicide (Times News Network, 2013; Odisha, 2014). Richard S. Lazarus Professor of Psychology from University of Berkeley in United States stated that stress occurs when an individual perceives demands of an external situation beyond his or her perceived ability to cope. He suggested that stress definition is neither the environmental event, nor the person's response; rather describe the individual's perception of the psychological situation is the critical factor in defining his stress theories. Lazarus theory and definition of stress is widely use and commonly accepted in defining theory of stress (Cassim, 2013). Lazarus worked largely on human in testing his stress theory. According to Lazarus (2000), the ability of human to think and evaluate future events makes them more vulnerable to stress than animals. Lazarus also explained that human encounter stress because they have high level of cognitive abilities that other animal lack. Lazarus together with Folkman (1984) was prominently recognized for their Coping Mechanism theory. This theory is defined as amount of cognitive and behavioral efforts, that constantly changing which aims to handle particular demands, internally or externally that are viewed as challenging and demanding. Simply, coping is the activity we do to seek and apply solutions to stressful situations or problems emerge due to the stressors.

Stress has been largely covered and extended in multiple fields of study and by numbers of scholars from psychobiology, sociology, psychiatry as well as anthropology (Weber, 2011). In sociology, stress is best described by a theoretical framework that explains health disparities called social paradigm. Social paradigm defines social condition as a cause of stress for members of disadvantage social group (social group disadvantage which derived from prejudice, discrimination and stigma (Meyer et al., 2008). Sociology stress studied the inequalities exists in physical and psychological well-being in a particular society. For example, the study of how woman live significantly longer than men but they suffer more serious acute transient illnesses, more chronic health condition, and more serious functional disabilities that men (Thoits, 2010). Meanwhile, besides in sociology, stress also occurs in organization. Organizational stress is a state of tension experienced by individuals facing extraordinary demands, constrains or opportunities (Brief et al., 1981). 
Manning \& Preston (2003) from University of Idaho define stress in organization as stress faced by employee as a result from decisions and implications made by organization which later could bring negative consequences to organization itself. The example of organization implication that cause stress to employee are staff incapable for coping up with organizational change, poor leadership quality from the managers or imbalance work-life style issues due to existence of technology (Manning \& Preston, 2003).

Stress studies in Malaysia: There has been few studies of stress in Malaysia context, among the studies were done in safety and security sectors (Barhem et al., 2004), educational sector (Al-Dubai et al., 2011; Yusoff et al., 2011; Faleel et al., 2012; Yusoff, 2011; Zawawi \& Jye, 2012) production sectors such manufacturing and infrastructure (Salleh at el., 2008; Nasarudin et al., 2005; Yahaya et al., 2011), military (Bokti \& Talib, 2009), stress among the retirees (Al-Naggar \& Chen, 2011) and the study on the source of stress among women work force (Bakar \& Abdullah, 2007) (Ortega et al., 2013). For stress in safety and security sectors, Barhemet al. (2004) observed the role stressors among Malaysian and Jordanian Customs Department employees. The major findings in this study showed that role ambiguity is the main source of work stress among the Malaysian and Jordanian customs employee. In educational sector, several studies were done and many of these studies examining stressors among medical students in public and private universities as well as stress perceived between low-and-high achieving students (Yasin \& Dzulkifli, 2011). One of the studies investigated the stress level among undergraduates' medical students in Management and Science University of Malaysia (MSU). The study showed that among 376 respondents, 174 students reported to experience some and too much stress while 23 students reported to experience no stress at all. From 174 students who stress, $71 \%$ of the stressor was contributed by future worries whilst conflict with teachers contributed the least number with only 22.6\% (Al-Dubai et al., 2011). The other study that examining medical students in public universities showed that academic matter such test and examinations, too much learning content, poor marks, study expectations and insufficient medical skills are the top-most stressors among these medical students (Yusoff et al., 2011).

In higher learning institutions, a study from University Putra Malaysia investigated the stressors and coping strategies among MBA students in renowned Business School in Malaysia. Three major stressors were identified; academic related stress, time related stress and social/environment related stress with academic related stress is a major contributor towards stress among 150 respondents of MBA students (Zawawi \& Jye, 2012). With regards to stress among managers and workers of manufacturing and infrastructure industries, few studies were conducted. Salleh et al. (2008) did the study to investigate the source of stress among executives in furniture industry and later identified that $35.8 \%$ of respondents felt very stressful at work due to unrealistic objectives, issue of incompetent boss, time pressure and deadlines. Other study of stress with regards to examine organizational stressors and job stress among managers in electronic firms in Island of Penang, found that conflict blocked career and alienation has positive relationship to job stress. However, according to these managers, work overload, has no significant relationship with job stress (Nasarudin et al., 2005).

Theoretical Framework: Teaching, research and administrative work are 3 important components in academician's job in academic industry nowadays, therefore these components were selected as dimensions to be studied in measuring work responsibility stress among academicians in private universities. The lists of elements listed on the framework are attributes which will be included and examined in this study. These dimensions were taken from literature review and academicians' key performance indicators in public university as guidance. Proposed Theoretical Framework of the relationship between stress and academician job responsibility in private universities is represented on the following page as Figure 1:-

\section{Methodology}

The sampling frame or unit of population in this study is academicians in private universities in Malaysia, with the total populations of academicians of about 26, 438 (MOHE, 2012). There are 37 private universities in Malaysia. A total of 200 respondents consist of academicians from private universities in Malaysia will be identified to respond to this study. The survey questions will be designed and distributed physically by the researcher to the respective academicians in order to get higher response rate. This research will adapt only quantitative approach. This survey will include 4 sections, where section (1), (2) and (3) use close - ended 
questions and section (4) contains open- ended questions. Open-ended question is design to allow the respondents to give their own opinion and answers. In order to validate and explore the framework, an interview will be done on selected educators to justify the relevance of selected attributes and dimensions. The aim of the interview is to determine the finalized dimension of stress as perceived by educators

\section{Figure 1: Proposed Theoretical Frameworks}
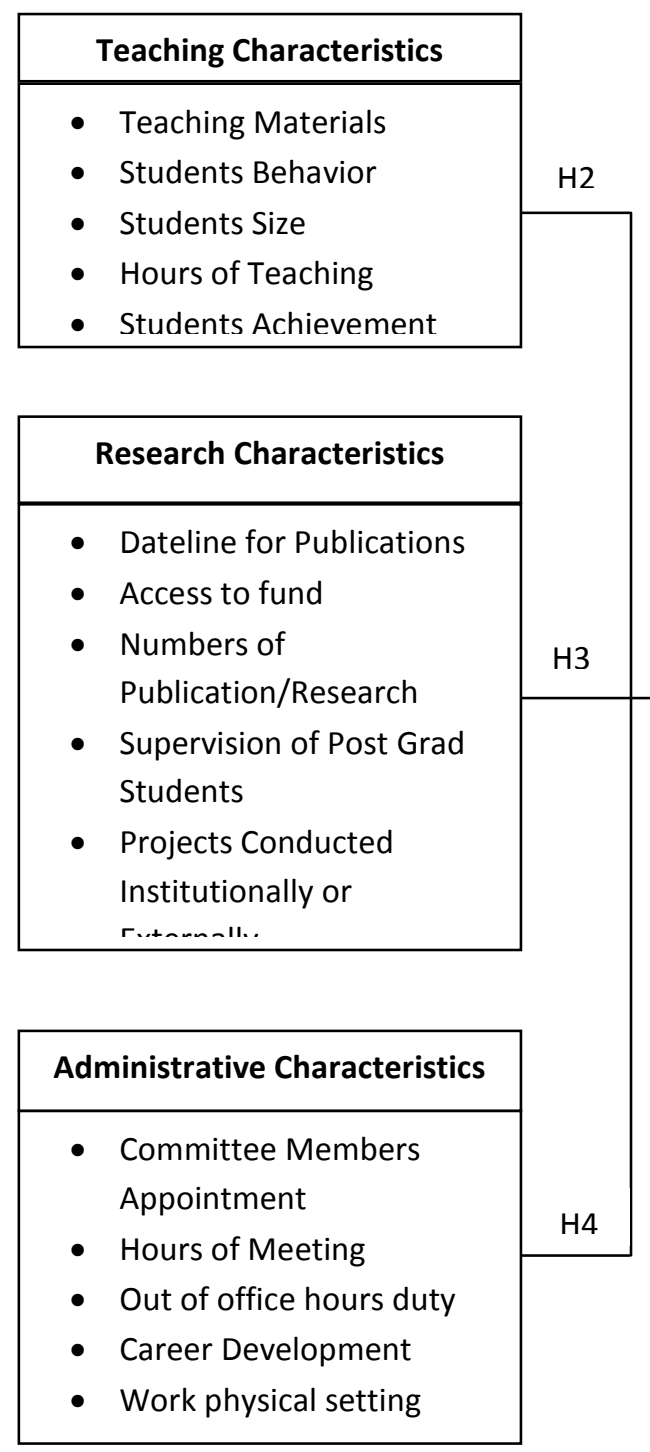

Independent Variables

\section{Conclusion}

There are small numbers of a study with regards to stress among academician in private universities in Malaysia unlike academic stress in public university. This study will infer on how stress is perceived by academicians in private universities as they receive more pressure working in an organization which independent, profit-oriented and highly dependent to fees as source of funding. The study of contributing stress factor in terms of academician's job responsibility is also a new topic yet to be discovered by any previous scholars; therefore this study is prominent contribution to the knowledge in academic world nationally and internationally. Also, it is hope that this study has the value of replicability in near future; for adaptation and further exploration purposes in order to provide broader perspective on stress. 


\section{References}

Al-Dubai, S. A. R., Al-Naggar, R. A., Al-Shagga, M. A. \& Rampal, K. G. (2011). Stress and Coping Strategies of Students in Medical Faculty in Malaysia. The Malaysian Journal of Medical Sciences, 18(3), 57-64

Al-Naggar, R. A. \& Chen, R. (2011). Stress and Coping Strategies among Retired People in Malaysia: A Qualitative Study. ASEAN Journal of Psychiatry, 12(2).

Arokiasamy, L., Ismail, M., Ahmad, A. \& Othman, J. (2009). Background of Malaysian Private Institutions of Higher Learning ad Challenges Faced by Academics. The Journal of International Social Research, 2(8), 1-8.

Bakar, N. A. A. \& Abdullah, N. (2007). Labor Force Participation of Women in Malaysia. International Economic Conference on Trade and Industry. City Bay View Penang, Malaysia, 3-5 December 2007.

Barhem, B., Sidin, S. M., Abdullah, I. \& Alsagoff, S. K. (2004). A New Model for Work Stress Patterns. Asian Academy for Management Journal, 9(1), 53-77

Bokti, N. L. M. \& Talib, M. A. (2009). A Preliminary Study on Occupational Stress and Job Satisfaction among Male Navy Personnel at Naval Base in Lumut, Malaysia. The Journal of International Social Research, 2(9).

Brief, A. P., Schuler, R. S. \& Shell, M. V. (1981). Managing Job Stress, Little Brown and Company.

Bunoti, S. (2011).The Quality of Higher Education in Developing Countries Needs Professional Support. Paper presented at 22nd International Conference on Higher Education. Retrieved from http://www.intconfhighered.org/FINAL\%20Sarah\%20Bunoti.pdf

Cassim, L. (2013). Optimal Health and Post Grad Study: A Focus on Wellness, Stress Management and Pharmaceutical Services', paper presented at the $2^{\text {nd }}$ National Post grad Development Imbizo, May, 13, 2013, Braamfontein, Johannesburg, South Africa.

Cooper, C. L. \& Dewe, P. J. (2004). Stress: A Brief Story Oxford: Blackwell

Faleel, S. F., Tam, C. L., Lee, T. H., Har, W. M. \& Foo, W. C. (2012). Stress, Perceived Social Support, Coping Capabilities and Depression: A Study of Local and Foreign Students in Malaysia Context. World Academy of Science, Engineering and Technology, 61(13), 75

Fink, G. (2010). Stress Science: Neuroendocrinology. Edited by Fink, G, San Diego, Elsevier Inc.

Fisher, C. D. \& Gitelson, R. (1983). A Meta- analysis of Correlates of Role Conflicts and Role Ambiguity. J. Appl. Psychol, 68, 320-333

Folkman, S. (1984). Personal control and stress and coping processes: A theoretical analysis. Journal of Personality and Social Psychology, 46(4), 839-852.

Hurtado, S., Eagan, M. K., Pryor, J. H., Whang, H. \& Tran, S. (2012). Undergraduate Teaching Faculty: The 20102011HERI Faculty Survey. Los Angeles: Higher Education Research Institute, UCLA

Halim, M. A. S., Zakaria, Z., Hussain, S. H. M., Kamaludin, M. A. \& Luqman, A. (2014). The Mediating Effect of Relational Norms in Determining Relational Satisfaction of Private Higher Learning Institution $5^{\text {th }}$ International Conference on Business and Economic Research (5 ${ }^{\mathrm{TH}}$ ICBER 2014) Proceeding Kuching, Sarawak, 24-25 March 2014.

Jackson, S. E. \& Schuler, R. S. (1985). A Meta-analysis and Conceptual Critic of Research on Role Ambiguity and Role Conflict in Work Settings. American Academic Press 1985

Jaschik, S. (2013). Who Says Academics Aren't Stress Out? Available from: http://www.theaustralian.com.au/higher-education/who-says-academics-arent-stressedout/story-e6frgcjx-1226550613135

Juliana, J. \& NurAqilah, M. Y. (2012). Association between Occupational Stress and Respiratory Symptoms among Lecturers in Universiti Putra Malaysia. Global Journal of Health Science, 4(6)

Johnson, M. W., Parasuraman, A., Futrell, C. M. \& Black, W. C. (1990). A Longitudal Assessment of the Impact of Selected Organizational Influences on Sale People's Organizational Commitment during Early Employment. Journal of Marketing Research, 27, 333-344

Kalleberg, A. (2001). The Advent of Flexible Workplace: Implications for Theory and Research. In Cornfield, D., Campbell, K.B., McCammon, H.J, (Eds) Working in Restructured Workplace: Challenges and New Directions of Sociology. Thousand Oaks, CA: Sage pp. 437-453

Lazarus, R. S. (2000). Toward better research on stress and coping. American Psychologist, 55, 665-673.

Lee, D. (1997). Employee Stress. John Liner Rev., 11, 3-7

Levin, H. M. (1991). Raising Productivity in Higher Education. The Journal of Higher Education, 62(3), 241-262

Lortie, D. C. (1986). Teacher status in Dade County: a case of structural strain. Phi Delta Kappan, 67(8), 568-75. 
Teichler, U. \& Koogan, M. (2007). Key Challenges to the Academic Profession UNESCO Forum on High Education Research and Knowledge Paris

Manning, D. \& Preston, A. (2003). Organizational Stress Focusing on Ways to Minimize Distress Summer Journal.

Meyer, H. I., Schwartz, S. \& Frost, D. M. (2008). Social Patterning of Stress and Coping: Does Disadvantaged Status Confer More Stress and Fewer Coping Resources. National Institute of Health, Social Science Media, 67(3), 368-379.

Nasarudin, A. M., Ramayah, T. \& Kumaresan, S. (2005). Organizational Stressors and Job Stress among Managers: The Moderating Role of Neuroticism. Singapore Management Review, 27(2), 63-79

Nazari, K. \& Emami, M. (2012). Antecedents and consequences of organizational commitment. Interdisciplinary Journal of Contemporary Research in Business, 3(9), 484-493

Odisha. (2014). Lecturer Suicide. Available:http://www.thestatesman.net/news/35297-lecturersuicide.html. Last Accessed Date: 20 February 2014.

Ortega, A., Abdullah, H., Ahmad, N. \& Ibrahim, R. (2013). Stress Indicators and Eating Habits among Working Malaysian Women. Asian Social Science, 9(7)

Oxford University Press. (2014) Oxford Dictionaries Available at: http://www.oxforddictionaries.com/definition/english/stress [Accessed 20 April 2014]

Pey, S. C. (2009). Research Environment of Malaysian Private Higher Education Institutes: Features, Funding and Policy Implications Asia Pacific Sub-regional Preparatory Conference for the 2009 World Conference on Higher Education: "Facing Global and Local Challenges: The New Dynamic for Higher Education" Macau, PR China, $25 \quad-26$ Sept, 2008. Available at: http://guides.is.uwa.edu.au/content.php?pid=43218\&sid=381005 [Accessed on 15 April 2014]

Pierce, M. \& Molly, B. (1990). Psychological and biological differences between secondary experiencing high and low lev-els of burnout. British Journal of Educational Psychology, 60, 37-51.

Porter, R. (1997). The Greatest Benefit to Mankind. A Medical History of Humanity, Norton.

Salleh, A. L, Bakar, R. A. \& Keong, W. K. (2008). How Detrimental is Job Stress: A Case Study of Executives in the Malaysian Furniture Industry. International Review of Business Research Papers, 4(5), 64-73.

Simha, A., Mousa, F. M. \& Kim, S. K. (2011). Jack and Jill Fall Down The Stress Filled Hill: An Integrative Management Educational Model to Prevent Such Stressful Slides. African Journal of Business Management, 5(19).

Smith, V. (1997). New Forms of Work Organization Anu. Rev. Sociol, 23, 315-339

Sutton, R. (1984). Job stress among primary and secondary school teachers: its relationship to ill-being. Work and Occupations, 11, 7-28.

Thoits, P. A. (2010). Stress and Health: Major Findings and Policy Implications. A Journal of Health and Social Behavior, 51(S), S41-S53

Times News Network. (2013). Guest Lecturer of Bundelkhand Commits Suicide. Available:http://timesofindia.indiatimes.com/city/kanpur/Guest-lecturer-of-Bundelkhandcommits-suicide/articleshow/20266533.cms. Last Accessed Date: 20 February 2014

Van Sell, M., Brief, A. P. \& Schuler, R. S. (1981). Role Conflict and Role Ambiguity: Integrations of Literature and Directions of Future Research. Journal of Human Relation, 34, 43-71

Weber, J. G. (2011). Individual and Family Stress and Crisis, California, Sage Publications Ltd.

Yahaya, A., Yahaya, N., Bon, A. T., Ismail, S. \& Ing, T. C. (2011). Stress Level and Its Influencing Factors among Employees in Plastic Manufacturing and The Implication Towards Work Performance. Elixir Psychology, 41, 5932-5941. Available at: www.elixirjournal.org, Accessed: 20 October 2013.

Yasin, M. A. S. D \& Dzulkifli, M. A. (2011). Differences in Depression, Anxiety and Stress between Low-andHigh Achieving Students. Journal of Sustainability Science and Management, 6(1), 169-178

Yusoff, M. S. B (2011). Stress, Stressors and Coping Strategies Among Secondary School Students In Malaysia Government Secondary School: Initial Findings. ASEAN Journal of Psychiatry, 11(2).

Yusoff, M. S. B., Yee, L. Y., Wei, L. H., Siong, T. C., Meng, L. H., Bin, L. X. \& Rahim, A. F. A. (2011). A Study on Stress, Stressors and Coping Strategies among Malaysian Medical Students. International Journal of Students' Research, 1(2).

Zawawi, D. \& Jye, K. S. (2012). Understanding the Stressors and Coping Strategies Among MBA Students in Malaysia. In: The 2012 International Conference on Business and Management Phuket, Thailand, 67 September 2012. 